\title{
FEMINIZATION OF TEACHING IN BANGLADESH: EXPLORING THE INFLUENCE of State, MARKeT, AND FAMILY
}

\author{
Shamnaz Arifin Mim \\ BRAC Institute of Educational Development, BRAC University, Dhaka, Bangladesh \\ E-mail: shamnaz.arifin14@gmail.com
}

\begin{abstract}
Although the number of women teachers is increasing in primary schools, the profession is often devalued considering social prestige and remuneration. This review article thus aims to explore the ways in which existing structures of the state, markets, and families in Bangladesh are leading to feminize primary school teaching. By adopting a gender lens, this study is mainly supported by kinds of literature, policy documents, and guidelines were 'teaching as a feminized profession' has been conceptualized in a global-local context. The study argues that states' existing policies regarding primary school teaching is politicized in a way that it encourages women and devalues the profession at the same time. This critical descriptive review reveals how income status within the home can shape masculine and feminine work experiences and how the whole process of teaching gets cheaper with the presupposed gender-roles. The household ideology within patriarchal structures encourages women to pursue this profession which provides them enough time to take care of the family. Finally, the societal fabrics of the market and heteronormative ideas of family are found as intertwined with the state's intervention to feminize primary school teaching. This study would therefore hopefully lead to change gendered mindsets of not only the policymakers but also of both the men and women themselves who should pursue primary teaching as a profession where they genuinely can contribute regardless of their gender-roles.
\end{abstract}

Keywords: Feminization; Primary School Teaching; Gender; Bangladesh

\section{INTRODUCTION}

In Bangladesh, women teachers already outnumber men in the primary education sector (BANBEIS, 2013). The primary education administration of this country is still demanding more women teachers with the assumption that they are more suitable than men for this profession (MoPME, 2015). From my personal experience being a school teacher back in 2011, I found that women teachers are usually more satisfied than men with a low salary and they have the notion that elementary teaching goes more with their lifestyles. Nonetheless, the number of primary school women teachers is increasing by time (See Appendix 1) as women get enough time to care for their families in this profession (Tasnim, 2006; Hofstede \& Hofstede, 2005). About 63\% of total teachers were women in government primary schools until 2012 (BANBEIS, 2013). But the crucial thing is, although the number of women teachers is increasing in primary schools, the profession is getting devalued considering social prestige and remuneration. This situation is politically interlinked by the role of the state, market, and family. To solve this social problem I think it is needed to be addressed how primary school teaching is feminizing in this $21^{\text {st }}$ century in Bangladesh.

The focus of this paper is thus to explore the ways in which existing structures of the state, markets, and families in Bangladesh are leading to feminize primary school teaching. This paper particularly highlights the policy for primary school teachers by the Ministry of Education, Bangladesh and gives specific consideration to a key question: How do the state, market, and family create feminization in the primary school teaching profession in Bangladesh? Here I emphasize specifically on governmentowned primary education since the number of Government Primary Schools (GPS) is highest, other types of schools generally follow the curriculum and administration process of the GPSs (Tasnim, 2006). Young, married/unmarried and middle-class Bengali heterosexual women, who are the majority in Bangladesh, are the main focus for gender analysis. To find out the answer, I have conceptualized 'teaching as a feminized profession' in a global-local context and have defined my position to look into it. By adopting a gender lens, this critical descriptive review of research articles and policy documents has presented an analysis of 
the influence of the state, market, and family to feminize primary school teaching. A discussion on the overall analysis reflecting more on the state's intervention on women teacher's involvement in primary schools intertwined with market and family influences is presented before placing the concluding notes.

\section{A FEMINIZEd PROFESSION: Primary School Teaching}

The history of education in the western world showed that after the industrial revolution the job opportunities for men expanded highly. Industrialization created new jobsectors with a better salary structure than elementary teaching. As a consequence, in many parts of Europe, women started to enter into this profession during the mid$19^{\text {th }}$ century widely. Conversely, men tended to work on more elite education, particularly secondary and tertiary education rather than elementary teaching. Slowly but surely, women encouraged to become a primary school teacher which gave the opportunity to at least work out of the home with recognition (Griffiths, 2006). By the time, elementary teaching was no longer possessed a "high-status" for men. Since the primary schools started offering women largely, middle and/or working-class men viewed this profession, not a suitable one for them (Skeleton, 2012). Consequently, primary school teaching gradually becomes a feminized profession.

The feminization of primary school teaching is a global phenomenon. From 1950 to 1990 in Germany, 'there has been a clear reduction of social prestige within sections of the teaching profession concurrent with the increase of women active within education' (Basten, 1997: 57). This difference is mainly in primary schools, considering this as a less academic form of school, but not in grammar schools in Germany (Basten, 1997). Drudy (2008) found in Ireland that, the number of male teachers dropped rapidly in the $20^{\text {th }}$ century with the assumption that female teachers are ideal candidates for primary schools. In his view, 'the manner in which the feminization of teaching has occurred involves subtle patterns of socialization in Western cultures. In many western societies, there has been an ideological link between women's domestic roles and their commitment to teaching' (Drudy, 2008: 312). This perception helped to increase women's teacher's numbers, especially in Bangladesh, Nepal, and India during the $21^{\text {st }}$ century (Tasnim, 2006).

The concept 'feminized profession' often bears overlying connotations. Different people have defined this term differently over time. Several authors have focused on the increased percentage or higher proportion of women teachers to define it (Krecker, 1974; Schmude, 1988). Moreover, 'one anti-feminist argument is that men's absence is a major contributory factor to its lower status amongst the profession' (Skeleton, 2012: 8). Initially, it was meant to the higher proportion of women in teaching. But feminization is not completely related to the large numbers rather the reduction of social status, salary structure and feminine interpretation of teacher's activity are considered to feminize the teaching profession (Basten, 1997). That means 'feminization of teaching' can be defined in terms of the higher percentage of women teachers and/or their social prestige. In this paper, I aim to dig deeper into the second conceptualization of 'feminized profession' to place my argument.

\section{FEMINIZATION THROUGH STATE, MARKET, AND FAMILY: ANALYSIS OF THE SITUATION}

In this $21^{\text {st }}$ century, Bangladesh is still a highly patriarchal society where gender inequality is rooted in every sphere of life (Tasnim, 2006). As a result, women are always in a lower position in gender hierarchies which creates problems even for educated women to work with a high prestige equal to men in various job sectors (Mim, 2015). However, research showed teaching is considered one of the most suitable jobs for women in Bangladesh, basically for young middle-class women (Mahtab, 2007; Mim, 2015). It is worth mentioning here that, making a job suitable for anyone to achieve gender equity should practically not be a problem, but it demands to be under consideration that, are we trying to feminize this profession particularly in the name of 'suitability'? In the following, I analyze the nuanced ways of the feminization of the primary teaching profession by visiting the influential roles of state, market, and family.

\section{A. The State}

After the liberation in 1973, about 36,200 primary schools were publicly owned and the teachers working on those schools were considered as government workers in Bangladesh. The overall implementation and management of primary education are now controlled by the government. Government Primary Schools are completely under the responsibility of the state where teachers got their salary from the revenue budget of the government and their recruitment and training are also provided by the state (MoPME, 2015). Since the state is the main controller of the whole primary education system, my arguments in this section thus somehow stand against the state's role in influencing the society to play gendered stereotype roles in their professional as well as family life.

Focusing on the Bangladesh constitution and the decisions by the Ministry of Primary and Mass Education for women teachers are important to tease out the reason why I made the state responsible for feminizing primary teaching. The entry requirement of male and female teachers in primary schools is different; HSC (Higher Secondary School Certificate) is the minimum education level for males whereas the female-only needs to pass in SSC (Secondary School Certificate) level. This discrimination goes with article 28(4) from the constitution of the People's Republic of Bangladesh where it has been written to give many favors to the women. The state has also been considering the women as the backward section of the nation and that is why provide different opportunities for women teachers (Tasnim, 2006; The Constitution of People's Republic of Bangladesh, 1972). For such privileges women are getting more into primary school teaching but why this opportunity is not provided in other academic jobs of the country? I assume the reason lies in reserving a $60 \%$ quota for women teachers by 
the state. The state simply indicated that the reason for this quota is expecting women teachers as the substitute of students' mothers in the classroom (MoPME, 2015; Tasnim, 2006). This clear gendered assumption is the basis of all the so-called opportunity for women in this particular profession. Here the society wants women as a "good mother" who is supposed to be nurturing, caring and compassionate by born. It is basically 'based on the essentialist belief that a woman's nature tends to make her better with children' (Drudy, 2008: 312 ). So this is undoubtedly problematic which questions women's identity.

Mothers in the family are considered as the most tolerant person who looks after all sorts of demands of the family members. Whereas, Drudy (2008) mentioned that primary school teaching has been thought of as the most unattractive and boring profession by the general mass where too much patience is required to deal with the kids. Here we find a relation has been made up between teaching and mothers' role in terms of patience. Consequently, the state has ensured several opportunities to enter into this job i.e. married women teachers can transfer to her husbands' posting (MoPME, 2015; Tasnim, 2006) so that she can also play her divine duty of homemaking perfectly. I find it extremely politicized and generalized of women's role in society.

However, the legal age of marriage is also different for males and females in Bangladesh; 18 for girls and 21 for boys (Plan Bangladesh, 2013). Unfortunately, recently the government has passed a controversial law which says marriage involving underage brides or grooms will not be considered an offense if they take place with the consent of the court and the guardians in "special contexts" serving the "best interest" of the underage female (Dhaka Tribune, 2017). Critics say the law will only "encourage" child marriages rather than curb the practice (Dhaka Tribune, 2017). Bangladesh has one of the highest child marriage rates in the world - about $65 \%$ of girls are getting married before 18 in Bangladesh (Plan Bangladesh, 2013). After entering into her husbands' house, she hardly manages time to continue the study by doing households. As primary school teaching requires minimum SSC passed women teachers, the middle-class wives who really want to engage in a job by maintaining a patriarchal family's home demands prefer this profession. Such societal issues also illustrate how the existing laws by the state are interwoven to direct the middle-class women to choose this profession. These various policies of state highly influence their lives where they find themselves in the lower hierarchies of power and feel these differences as a natural process which is also legitimized by the families. Thus by drawing on Basten's (1997) idea on the feminized profession, the aforementioned state's decisions and laws encourage more women in the primary teaching which also often position women in lower societal status by making their profession feminine.

\section{B. The Market}

The $60 \%$ quota reservation policy by the state has already facilitated more women teachers to join in primary schools even in the existing poor salary structures (MoPME,
2015). The status of the teacher labor market in Bangladesh thus shows that women teachers are increasing in the primary sector every academic year due to their reserved position and men, leaving primary teaching, prefer other jobs since teaching in Bangladeshi schools does not come with handsome salary structures (Tasnim, 2006). The salary varies between 5,000 to 16,000 Bangladeshi Taka where the minimum wage is the same as a garment worker and much less than government or corporate job employees (Mim, 2015; Devnath, 2013).

The perception regarding this position and financial structures often varies in terms of socially prescribed gender roles. Research showed male teachers are usually very gratified with the masculine environment, job security and other flexibilities at schools yet the low wage creates high dissatisfaction among them which leads to, less interest in this job. Conversely, despite having dissatisfaction regarding promotion, masculine supervision and the social environment of the school, women teachers are less money concerned than men by thinking that they are holding good positions in relation to their academic achievements (Boyd et al., 2002; Tasnim, 2006). Here my argument is consistent with Basten (1997), where I assume how the poor salary structures and social status of this job politicized with the stereotyped gender roles in a way that it feminized the profession. Moreover, the patriarchal society expects men to work in such sectors where they will be able to play their role as the main breadwinner of the family with high income. As a result, according to Cha and Thebaud (2009), middleclass men are interested to have such a rigid labor market which helps them to maintain the primary breadwinner image because this breadwinning identity is one of the fundamental elements of men's masculinity. These structural conditions lead to exercise the socially prescribed gender roles to both men and women. In turn, to protect this masculine image of the husbands, middle class educated women to feel comfortable to work as an elementary school teacher with such low wages. Despite many social constraints, these women thus feel more satisfied in this job sector than their male counterparts and found prestigious to have the opportunity to at least work rather thinking about the salary. Here I also agree with Fraser (2013), a renowned feminist theorist, who said thinking only about the access to the job is not enough, in Fraser's (2009: 1) view, 'deeply gendered, this "family wage" construct served both as a social ideal, connoting modernity and upward mobility, and as the basis for state policy in matters of employment, welfare and development'. My ideas are consistent with this also because it not only reveals the gender power relations in both family and market but also depicts how income status within the home can shape masculine and feminine work experiences. Thus, gender works to categorize the masculine and feminine labor market by providing space to exercise the gendered societal fabrics.

In the patriarchal society, girls are often socialized in a way that nurturing children is something intrinsic (Stromquist, 2007). As a consequence of expecting such gendered performances, society assumes that women, in 
general, are very comfortable with the motherly-work, like, taking care of and dealing with children. Elementary teaching, therefore, perceived as an appropriate job for women that they can do naturally. This assumption by the gendered society leads women to have less training on handling children. The whole process is getting cheaper with these presupposed gendered roles where the government allocates small budgets in teachers' training and as a consequence, the market is getting benefited gradually. My argument here is consistent with Enloe (2014) who said that this cheapening is not an automatic process rather the dogma of femininity is endowing the state to do so.

\section{The Family}

Extended families are the most common in Bangladesh where heterosexual married couples live with more than two generations. Grandfathers are usually the decision-makers for the family members. The existing patriarchal structures within these types of families influence women to choose their area of the labor market since they are considered as the subordinate of their husbands where their gender roles do not often allow them to choose a masculine profession like an engineer, lawyer, scientist, administrator, etc. (Mim, 2015).

While men act as the first breadwinner of the family, it automatically pushes women to play a certain expected role in the patriarchal family by positioning themselves in the lower strata of the gendered hierarchical structures (Agarwal, 1997). The gender power relation in such families normalizes that women are bound to do household tasks even when they are not interested. Society demands an "obedient" wife who will meet the demands of all the members of the family. Here my argument is consistent with Griffiths (2006), where I assume that to cope up with the politics of devoting enough family time and job status, women are encouraged to choose primary school teaching not only because it has less working hours comparative to other jobs but also the work calendar in sync with the school going kid at home. Thus this profession provides enough time to support and take care of the family members after coming back from the workplace which ultimately gives space to exercise the stereotypical gender roles and to create gender-binaries in defining masculine and feminine works.

At this point in the analysis, a question can also be raised that, though Bangladeshi women from middle-class educated families are working in full swing, have we thought for which jobs and why? The answer to this question cannot stand alone except considering the argument of this paper that why middle class educated families encourage women to take the elementary teaching profession. For some obvious reason, so-called "modern educated" husbands somewhat want their wives to engage in the productive labor market. On one side, the wives find it as an opportunity to utilize their educational potentiality and on the other side, by giving the permission of getting into jobs the husbands successfully position themselves in much upper stage of greatness. The husband, therefore, becomes a 'perfect' man by letting his wife doing jobs outside the home.
Additionally, it is true that nowadays in Bangladesh, though husbands are encouraging their wives to work outside home in middle-class dual-earner households; they can adopt less gender-egalitarian ideology than wives which is consistent with Cha and Thebaud (2009). Research showed. 'the vast majority of men do less housework than their gainfully employed partners' (Hochschild, as cited in Parrenas, 2001: 70), as a result, majority of those working women have to do childcare, elderly care, cooking, cleaning and all types of household chores. Thus this situation is in keeping with Parrenas (2001) who said that such unpaid household labor which we often considered as reproductive labor requires much time and to manage time for these works family advise women to take elementary teaching as a profession.

Moreover, the desired interest of both married and unmarried women to become careerists is hardly taken positively by the middle-class patriarchal families in Bangladesh. The traditional gender norms demand a woman to be committed to her family to such an extent where her one of the major roles is to serve the husbands' pleasure so that he can become more successful in the workplace (Cha \& Thebaud, 2009). The reason behind this is consistent with Parrenas (2001) who claimed that success is often measured by high income and the socialized identity of patriarchy destroys if the man earns less than the wife. Not only have that, but the middle-class family members also are not seen to be concerned about women's promotion or salary status. However, like this, the family encourages the girl to join as a teacher near local schools so that she can provide service restlessly in both places without using her agency. This practice is nothing but trying to establish misogyny where the men possess an attitude of having fear of women's success and empowerment which is consistent with Enloe (2013). Thus by drawing on Skeleton's (2012) idea on the concept 'feminized profession' I assume that the societal structures of family engagement lead men in a way to avoid this job which works as a factor for it to hold the lower status among many other professions.

\section{IV.DISCUSSION}

\section{A. State Intervention Intertwined with Family and Market}

The above analysis revealed that the socio-economic and political aspects are feminizing this profession in Bangladesh. Thus the poor or middle class educated girls are not encouraged to take corporate jobs, military or heavy industrial jobs, etc. According to Enloe (2014: 285), 'this masculinized political influence undercuts women workers bunched together in light industries' and less academic jobs. On the other hand, in the primary teaching profession in Bangladesh women are not benefited from promotions like men though they have several opportunities to enter into this job (Tasnim, 2006). This result is quite similar to the studies in European countries during 1975 (Basten, 1997). Besides, political instability is one of the major problems of Bangladesh now. Different political parties have their internal conflicts and the general mass is struggling in such a situation. The Awami League is ruling for the last 6 years as 
government. The recruitment of teachers is often ensured by government political power. So it is very difficult for those middle-class women who do not have any political connections, which mean the process of getting into this job is highly based on patron-client relationship. Furthermore, these teachers are monitored and supervised by the masculine environment of the school. Women's employment is thus always exaggerated by the structural requirements of economy and politics (Schmude, 1988).

My argument for this section is consistent with Agarwal (1997: 32) who noted that 'the State has the power to enact laws and formulate policies and programs in women's favor; to increase women's access to productive resources, employment, information, education, and health' (Agarwal, 1997: 32) and with that power, the state law has created different opportunities for women to ensure their entry in the primary teaching profession. The $60 \%$ quota reservation is a remarkable one in this situation. The focus of this particular section of this paper is also to analyze the consequences and assumptions underlying this opportunity. The state obviously is implementing this law to help women to an extent but there lie several problems. The issue that pushes me to analyze further for such facilities is the recognition and representation of those women in second-wave feminism that Fraser (2009) actually talked about.

The quota reservation for women also can influence the middle-class men to not having an interest in primary teaching rather going for more elite education teaching i.e. higher secondary or tertiary level with the assumption of masculine nature of work. It seems to me that the different educational level of teaching has been politically structured with a different status where women belong from the lower level. At the same time, the men who are involved in primary teaching can have the possibility to devalue this profession as a feminine job. As a consequence, it can be assumed that this is one of the main reasons why the number of male primary teaching is decreasing day by day (See Appendix 1).

Moreover, state 'is a differentiated structure through which and within which gender relations get constituted, through a process of contestation' (Agarwal, 1997: 34) and there are some highly gendered consequences because of such intervention of the state. The analysis of this paper thus revealed why patriarchal society encourages women to take this job by exercising the politics of time and money which is consistent with Kabeer's (2000) argument on married women's choice for a career. The identity of women as "mother" influences her responsibility in both home and school. While a woman takes care of her children in the home it does not count as productive work and when she handles the students in school - it appears something very natural for women. Such normalized legitimacy allows women to earn less. Furthermore, while the men do those works, it seems to be much difficult for them as it is "women's work"! The socialization here is one of the crucial aspects that actually shape the overall experience of being men and women by practicing their gender roles and relationships. Here my ideas are consistent with Gherardi
(1995: 103) who affirmed that 'gender relations' are formed 'based on a normative order which reproduced femaleness and maleness through socialization'. Ultimately this structural condition comes with a tendency to undervalue and cheapen female labor for the economic benefit of the state. This discussion also provides a space to focus on the argument of Razavi (2007), where she asserts that women earn less because they have to work at home. The care economy of women leads to having such low paid works as they required spending enough time in household activities.

Though the quota opportunity sounds very attractive for the middle-class women who are burdened with family nurturing responsibilities, it is not that alluring for the rich or higher middle-class careerist women because they are much motivated to work in other organizations where they enjoy better salaries. I further perceive this quota intervention is highly targeting the middle-class women who have a "good wife/mother" image. As a consequence, the lack of financial muscle comparative to the male members of the family put these women in the lower echelons of power. This image of subordination with the motherly image of women is highly promoted by the state with that intervention. Apart from this argument, it is true that the state gave women the "opportunity" to become the 'breadwinner' of the family to some extent by the quota facilities, but the role of breadwinner is not equivalent to the upper position of gender power dynamics for women always. Here the family is a locus of a power struggle over resources where women are subordinate to males and lie in lower sexual hierarchies. Therefore, it is probably visible with the assumption that the intervention by the state for women's entry in the primary teaching profession consequences different problematic notions interlinked with patriarchal family responsibilities and the market. Such gendered institutions' ideologies are feminizing primary school teaching profession day by day. Probably, the reason behind not taking feminist action from NGOs yet is to ensure the access right of women in different workplaces first and then to move for second-wave feminism. The unrest political situation of the country may also be a reason for not questioning governments' intervention.

\section{CONCLUSION}

The broadened debate of family, workplace and the state has situated within the trajectory of second-wave feminism all over the world. The gender injustice exits in economic, cultural and political dimensions which lead to having low wages, job insecurity and poor living standard (Fraser, 2009) and this paper explored that situation in a particular case of Bangladesh. Overall, 'the feminization of teaching is a cumulative historical and social process' (Drudy, 2008: 312). Bangladesh is a country where primary teaching is paying less value compared to other professions. The involvement of women in this profession has been encouraged by both state and family where they are getting minimum wages. The patriarchal and capitalist society is gaining advantage with female teachers' labor but women hardly satisfied with the dominating masculine environment of the school. According to Drudy (2008: 312), 'the domestic ideology which 
provides cultural support for the notion that women's careers should be compatible with homemaking responsibilities...no such ideology existed to provide a connection between men's careers and homemaking/parental responsibilities'. Finally, the analysis guides to link that the lower pay-scale, household ideology and state's perception of the female teachers as a 'good mother' promotes feminization of primary teaching in Bangladesh. Here I would like to mention Griffiths (2006: 403) who noted that, 'hegemonic masculinity is a problem if it crowds out other practices...the greater the diversity of the teaching profession, and the less the power structures in society have a hold within it, the less viscous the practice'. Thus, my voice never stands against the job entry opportunities for any particular gender rather on how the societal fabrics of the market and heteronormative ideas of family are intertwined with the state's intervention in "gendering a profession".

\section{ACKNOWLEDGMENT}

I would like to thank Dr. Dubravka Zarkov, Associate Professor at the International Institute of Social Studies of Erasmus University Rotterdam for her valuable comments and guidance in developing the idea of this paper.

\section{REFERENCES}

Agarwal, B. (1997). "Bargaining" and Gender Relations: Within and Beyond the Household, Feminist Economics, 3(1): 1-51.

Bangladesh Beurue of Educational Information and Statistics (BANBEIS). (2013). Accessed 20 February 2015. http://banbeis.gov.bd/data/images/2pe.pdf

Basten, C. (1997). A Feminised Profession: Women in the Teaching Profession, Educational Studies, 23(1): 55-62. Accessed 1 March 2015. http://www.tandfonline.com/doi/pdf/10.1080/03055 69970230104

Boyd, D. et al. (2002). Understanding Teacher Labor Markets: Implications for Equity. Accessed 20 February

2015. http://www.albany.edu/edfin/UnderstdngTeachLab Mkts.BLLW.6.03.pdf

Cha, Y. and S. Thébaud. (2009). Labor Markets, Breadwinning, and Beliefs. How Economic Context Shapes Men's Gender Ideology' Gender \& Society, 23(2): 215-243.

Devnath, M. (2013). Bangladesh Raises Minimum Wage for Garment Workers After Unrest. Accessed 16 June 2016.

http://www.bloomberg.com/news/articles/2013-1113/bangladesh-garment-factories-to-stay-shut-amidworker-protests

Dhaka Tribune. (2017). Parliament passes law allowing child marriage in 'special cases'. Accessed 15 March

2017.

http://www.dhakatribune.com/bangladesh/lawrights/2017/02/27/child-marriage-bill-passed/
Drudy, S. (2008). Gender balance/gender bias: the teaching profession and the impact of feminization, Gender and Education, 20(4): 309-323. Accessed 19 February 2015. http://www.tandfonline.com/doi/pdf/10.1080/09540 250802190156

Enloe, C. (2013). Women in Recession. Austerity and Misogyny, in Seriously! Investigating Crashes and Crises as if Women Mattered. Berkeley: University of California Press. pp. 86-113.

Enloe, C. (2014). Women's labour is Never Cheap. Gendering Global Blue Jeans and Bankers, in Bananas, Beaches and Bases. Making Feminist Sense of International Politics. Berkeley: University of California Press. pp. 250-304.

Fraser, N. (2009). Feminism, Capitalism and the Cunning of History. NLR 56: 97-115. Accessed 18 November 2014.

https://www.newschool.edu/uploadedFiles/Faculty/ NSSR/Fraser_NLR.pdf?n=4644

Fraser, N. (2013). How Feminism Became Capitalism's Handmaiden, and How to Reclaim it, The Guardian. Accessed 7 December 2014. http://www.theguardian.com/commentisfree/2013/o ct/14/feminism-capitalist-handmaiden-neoliberal/

Gherardi, S. (1995). Gender, Sybmolism and Organizational Cultures. SAGE Publications.

Griffiths, M. (2006). The Feminization of Teaching and The Practice of Teaching: Threat or Opportunity? Educational Theory, 56(4): 387-405. Accessed 1 March 2015. http://onlinelibrary.wiley.com/doi/10.1111/j.17415446.2006.00234.x/full

Hofstede, G. and G. J. Hofstede (2005). Cultures and Organizations - Software of the Mind: Intercultural Cooperation and Its Importance for Survival. New York: McGraw-Hill.

Kabeer, N. (2000). The Power to Choose: Bangladeshi Women and Labour Market Decisions in London and Dhaka Verso, London, New York.

Krecker, L. (1974). Frauen im Lehrerberuf; Aspekte der Feminisierung und Fluktuation, Kaiserslautern (Georg Michael Pfaff Gedächtnisstiftung).

Mahtab, N. (2007). Women in Bangladesh, From Inequality to Empowerment Dhaka: A. H. Development Publishing House.

Mim, S. A. (2015). Can Women Science Teachers Be Role Models? Challenging Gender Stereotyoes of Science and Masculinity. MA thesis. International Institute of Social Studies (ISS). Erasmus University Rotterdam, The Hague, Netherlands. $\begin{array}{llll}\text { Accessed } & 12 & \text { June }\end{array}$ https://thesis.eur.nl/pub/33164/

MoPME. (2015). Ministry of Primary and Mass Education. Government of the People's Republic of Bangladesh. Accessed 5 March 2015. http://www.mopme.gov.bd/ 
Parrenas, R. S. (2001). The International Division of Reproductive Labour, in Servants of Globalization. Women, Migration and Domestic Work. Stanford: Stanford University Press. pp. 61-79.

Plan Bangladesh. (2013). Child Marriage in Bangladesh: Findings from a National Survey. Expressions Limited. Accessed 5 February 2015. http://planinternational.org/files/Asia/publications/nationalsurvey-on-child-marriage-by-plan-bangladesh-andicddr-b

Razavi, S. (2007). The Political and Social Economy of Care in a Development Context: Conceptual Issues, Research Questions and Policy Options. Gender and Development Programme Paper Number 3, United Nations Research Institute for Social Development, Geneva.

Schmude, J. (1988). Die Feminisierung des Lehrberufs an dffentlichen, allgemeinbildenden Schulen in BadenWürttemberg (Heidelberg, Geographisches Institut der Universität Heidelberg)

Skeleton, C. (2012). Men Teachers and The "Feminised" Primary School: A Review of the Literature, Educational Review, 64(1): 1-19. Accessed 27 February 2015 . http://dx.doi.org/10.1080/00131911.2011.616634

Stromquist, N.P. (2007). The Gender Socialization Process in Schools: A Cross-national Comparison, Education for All Global Monitoring Report 2008, UNESCO.

Tasnim, S. (2006). Job Satisfaction among Female Teachers: A study on primary schools in Bangladesh. M.Phil. Thesis. Norway: University of Bergen. Accessed 19 February

2015 . https://bora.uib.no/bitstream/handle/1956/1474/Mas teroppga?sequence $=1$

The Constitution of People's Republic of Bangladesh. (1972). Accessed 5 March 2015. http://bdlaws.minlaw.gov.bd/print_sections_all.php ?id=367
APPENDIX 1

Primary School Teachers Statistics in Bangladesh (till 2012)

\begin{tabular}{|l|l|l|l|l|}
\hline Year & Total & $\begin{array}{l}\text { Male } \\
\text { Teachers }\end{array}$ & $\begin{array}{l}\text { Female } \\
\text { Teachers }\end{array}$ & $\begin{array}{l}\text { Percentage } \\
\text { of Female } \\
\text { Teachers } \\
(\%)\end{array}$ \\
\hline 1990 & 160,869 & 127,777 & 33,092 & 20.57 \\
\hline 1991 & 160,098 & 126,341 & 33,757 & 21.1 \\
\hline 1992 & 156,480 & 122,700 & 33,780 & 21.6 \\
\hline 1993 & 157,633 & 120,104 & 37,529 & 23.8 \\
\hline 1994 & 159,149 & 119,325 & 39,824 & 25.0 \\
\hline 1995 & 158,658 & 115,950 & 42,708 & 26.9 \\
\hline 1996 & 161,458 & 116,250 & 45,208 & 28.0 \\
\hline 1997 & 158,057 & 113,655 & 44,402 & 28.1 \\
\hline 1998 & 153,247 & 105,392 & 47,855 & 31.2 \\
\hline 1999 & 158,317 & 105,072 & 53,245 & 33.6 \\
\hline 2000 & 158,216 & 104,588 & 53,680 & 33.9 \\
\hline 2001 & 162,090 & 101,082 & 61,008 & 37.6 \\
\hline 2002 & 157,236 & 98239 & 58,997 & 37.5 \\
\hline 2003 & 162,114 & 100,159 & 61,955 & 38.22 \\
\hline 2010 & 181,455 & 76,024 & 105,431 & 58.10 \\
\hline 2012 & 214,658 & 79,339 & 135,319 & 63.0 \\
\hline
\end{tabular}

Source: BANBEIS (2013), Tasnim (2006) 